\title{
Characterisation of homologues of known and putative dynein assembly factors in a Drosophila model
}

\author{
P zur Lage ${ }^{1 *}$, D Moore ${ }^{1}$, G Mali², E Hall ${ }^{2}$, P Mill ${ }^{2}$, A Jarman ${ }^{1}$ \\ From Cilia 2014 - Second International Conference \\ Paris, France. 18-21 November 2014
}

With only two types of ciliated cells, Drosophila is a useful organism in which to study conserved aspects of ciliogenesis. Cilia with motile characteristics in Drosophila are represented just by the sperm flagella and the sensory receivers of chordotonal neurons, which are proprioceptive and auditory sensory neurons.

We recently used Drosophila to identify two new putative dynein arm assembly factors, CG11253 (ZMYND10 homologue) and CG31320 (HEATR2 homologue): impairment of function of either gene results in flies with immotile sperm and defective sensory transduction due to lack of dynein arms in the cilia. We have sought to extend these observations to other known or putative dynein assembly factor homologues to determine how much of this pathway is conserved and set up Drosophila as a model for exploring the function of these proteins in further detail. This analysis has used transcriptomic data of developing chordotonal neurons, gene regulatory analysis (regulation by Rfx and Fox factor, Fd3F), genetic analysis of sensation and male fertility, and protein interaction analysis. Currently, we are also carrying out mass spectroscopy.

\section{Authors' details}

${ }^{1} \mathrm{SBMS} / \mathrm{CIP}$, University of Edinburgh, Edinburgh, United Kingdom. ${ }^{2} \mathrm{MRC}$

IGMM, University of Edinburgh, Edinburgh, United Kingdom.

Published: 13 July 2015

doi:10.1186/2046-2530-4-S1-P80

Cite this article as: Lage et al:: Characterisation of homologues of

known and putative dynein assembly factors in a Drosophila model.

Cilia 2015 4(Suppl 1):P80.

${ }^{1}$ SBMS/CIP, University of Edinburgh, Edinburgh, United Kingdom

Full list of author information is available at the end of the article

Submit your next manuscript to BioMed Central and take full advantage of:

- Convenient online submission

- Thorough peer review

- No space constraints or color figure charges

- Immediate publication on acceptance

- Inclusion in PubMed, CAS, Scopus and Google Scholar

- Research which is freely available for redistribution
C Biomed Central

\section{Biomed Central}

